\title{
Cultural and Personal Practices with Unusual Oral Findings: Three Case Reports and a Literature Review
}

\author{
Kawkab MA Al-Turck' \\ Sara Aldosary (D) \\ Reem Alrabiah' \\ Riham Albusayes ${ }^{2}$ \\ Sarah Alnamlah ${ }^{2}$ \\ 'Department of Oral Medicine and \\ Diagnostic Sciences, College of Dentistry, \\ King Saud University, Riyadh, Saudi \\ Arabia; ${ }^{2}$ College of Dentistry, King Saud \\ University, Riyadh, Saudi Arabia
}

\begin{abstract}
Due to increased migration, dentists are encountering patients with varied cultural practices. The main aim of this study was to report three cases in which cultural/individual oral practices appeared to be suggestive of disease, leading to initial misdiagnoses. We describe the case findings of three individuals treated at the Oral Diagnosis Clinic at the College of Dentistry at King Saud University in Riyadh, Saudi Arabia. In two cases, the patients presented with a missing uvula and dark maxillary gingiva. The initial diagnoses in both cases were incorrect. Further questioning revealed that the individuals had gingival tattoos and uvulectomies performed for traditional reasons. The patient in the third case presented with a diffuse red and white bilateral lesion on the buccal mucosa. The initial diagnosis was possible speckled leukoplakia. Upon further questioning, a definitive diagnosis of a chemical burn from a coarse salt mouth rinse due to personal oral practices was made. A literature review of these cultural practices is included. Our case report findings and the literature review highlight the need to consider cultural practices that can affect oral health and cause unusual oral findings when recording medical histories. Increasing awareness regarding these practices may help dentists provide appropriate treatment plans and reduce misdiagnoses. Furthermore, by understanding cultural practices, dentists may educate their patients about the harmful effects of some of these traditions.
\end{abstract}

Keywords: traditional practice, uvulectomy, gingival tattoo, chemical burns

\section{Introduction}

All health problems, including oral and dental diseases, are a product of social, cultural, and economic conditions, as well as individual, behavioral, and environmental factors. ${ }^{1}$ Despite worldwide advancements in dentistry, some people in minority ethnic groups still interpret and define health and diseases based on their traditional and cultural beliefs. ${ }^{2,3}$ Due to increased migration to industrialized countries, dentists are increasingly encountering patients with customs and cultures different from their own. ${ }^{3}$

Some traditional practices are destructive to oral and dental tissue. For example, charm needles or charm pins are talismans made by inserting needles made of silver or gold under the skin in various parts of the body including the orofacial region. ${ }^{4}$ This tradition is common in Southeast Asia and is believed to enhance positive traits, such as beauty, charisma, and health. In Sudan, a practice known as Hifat involves cutting swollen alveolar processes over unerupted canines with a sharp heated instrument to cure problems thought to be caused by teething. ${ }^{5}$ Moreover, in

\footnotetext{
Correspondence: Sarah Alnamlah College of Dentistry, King Saud University, P.O. Box: 60169, Riyadh,

I I545, Saudi Arabia

Tel +966544360366

Email sarahsaleh@gmail.com
} 
Southwestern Uganda, a practice called Ebiino, which translates to "false teeth", is a form of infant oral mutilation. ${ }^{6}$ Individuals who practice Ebiino consider the canine eminences to be foreign objects (worms or artificial teeth) that need to be removed to prevent or cure childhood diseases. The tradition involves rubbing infants' gums above the developing primary canine tooth bud area with herbs prior to gouging the tooth buds out at 48 months of age. ${ }^{7-9}$ Traditional uvulectomy is commonly practiced in Eastern Africa as a treatment for several throat conditions. It involves complete or partial removal of the uvula with non-sterilized instruments. ${ }^{10}$

Some cultures engage in practices that can complicate diagnosis. For example, people in some African cultures, particularly women in Senegal, engage in the intentional tattooing of the gingiva with traditional materials. Gingival tattoos must be distinguished from other pigmented lesions to prevent misdiagnosis and to avoid putting patients through unnecessary procedures. ${ }^{11}$ In addition, some personal oral practices may also lead to unusual oral findings that complicate dental diagnoses. Chemical or mechanical stimuli may cause burns in the mouth. Moreover, personal oral practices involving acidic or alkaline compounds and salts can damage the oral mucosa, mucous membranes, and lips. $^{12}$

If clinicians are not fully informed about their patients' oral histories, they may misinterpret the clinical significance of abnormal appearing oral tissues. In particular, dentists are likely to suspect an inflammatory disease, such as periodontitis. Recent findings have elucidated systemic signs of periodontitis, including elevated interleukin-6 levels, ${ }^{13}$ elevated galectin-3 levels, ${ }^{14}$ and an increased presence of NLRP3 (NACHT, LRR, and PYD domains-containing protein 3$)^{15}$ containing inflammasomes, which have emerged as clinically important biomarkers of inflammatory disease, particularly periodontitis. ${ }^{13-15}$ However, dentists may pursue unnecessary tests and treatments in an attempt to characterize and alleviate apparent lesions that they have attributed to diseases such as periodontitis in patients with tissues altered by their cultural or personal oral practices.

Although, the aforementioned cultural and personal oral practices have been described in the literature, they are unusual and rare incidental findings in the region of Saudi Arabia. The primary aim of this study was to share cases in which the physical effects of cultural and individual practices were initially mistaken for signs of oral disease. A secondary aim was to increase awareness of these practices, which may help dentists to provide appropriate treatment plans and reduce misdiagnoses. We thus report herein three cases with unusual findings produced by traditional practices and individual oral habits and underscore the need for dentists to consider cultural and personal practices that can affect oral health and cause unusual oral findings. Written informed consent was provided by all three patients for participation in this study and agreement to publish the case details and any accompanying images. All three patients were treated at the Oral Diagnosis Clinic at the College of Dentistry, King Saud University in Riyadh, Saudi Arabia. A review of the literature related to these practices and oral health is included.

\section{Case Reports \\ Case I}

A 37-year-old African woman sought dental treatment for caries. The patient's medical history was not relevant. Oral examination revealed a missing uvula (Figure 1A) and abnormal, diffuse, dark maxillary gingiva extending up to the
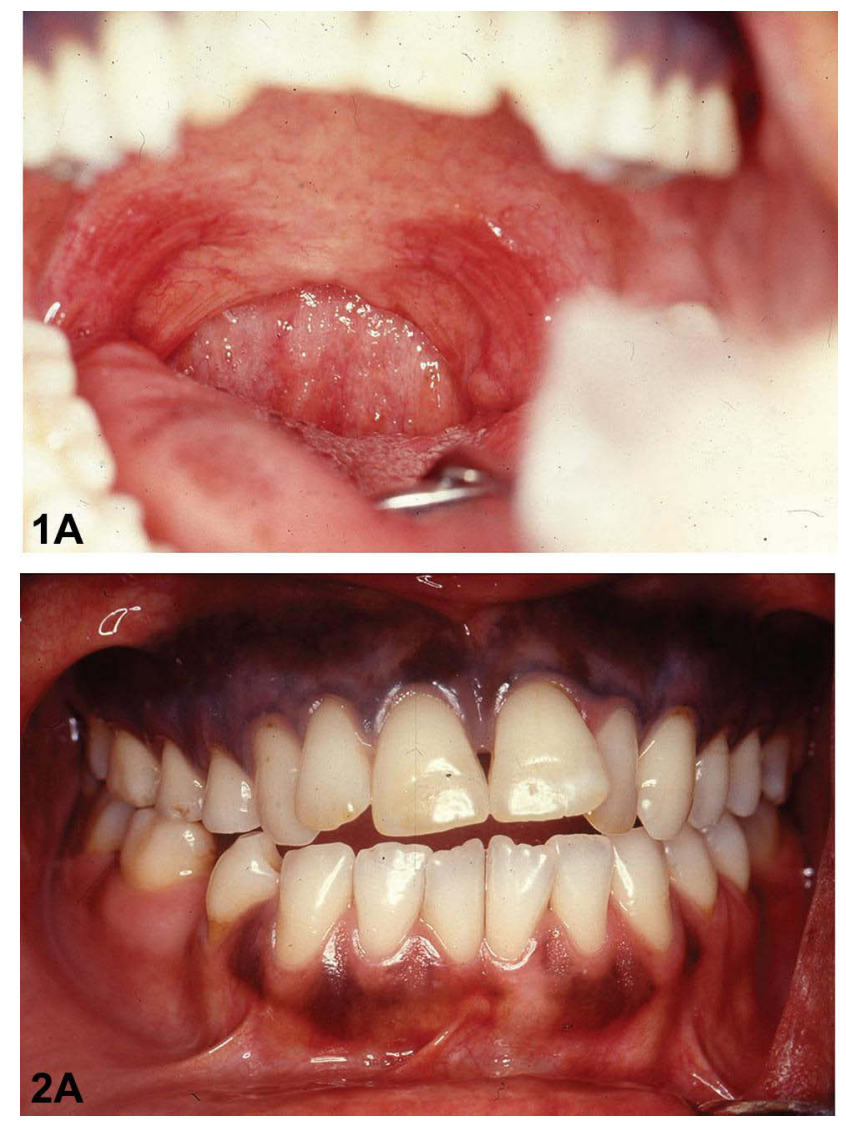

Figure I Case I. (A) Photograph of missing uvula. (B) Photograph of dark maxillary gingiva extending to the molars bilaterally. 
molars bilaterally (Figure 1B). The dark gingival color ranged from dark blue to grayish blue. Other areas of the gingiva, including the mandibular gingiva, were pink in color with scattered brown racial pigmentation. There was no edema, or gingivitis. The initial diagnosis was a congenitally missing uvula and possible diffuse melanoma. On further questioning, the patient stated that she had undergone gingival tattooing for traditional cosmetic reasons. Furthermore, the uvulectomy had also been performed for traditional reasons. No further treatment was required regarding these incidental findings. The patient was referred for complete dental treatment.

\section{Case 2}

A 65-year-old African woman requested a dental prosthesis for missing teeth. Her medical history included hypertension and treatment with an antihypertensive drug for the past 15 years. Oral examination revealed a missing uvula (Figure 2A) and multiple, scattered, dark bluish pigmentation areas on the maxillary gingiva extending bilaterally to the area of the first premolars (Figure 2B). Other areas of the gingiva, including the mandibular gingiva, were pink
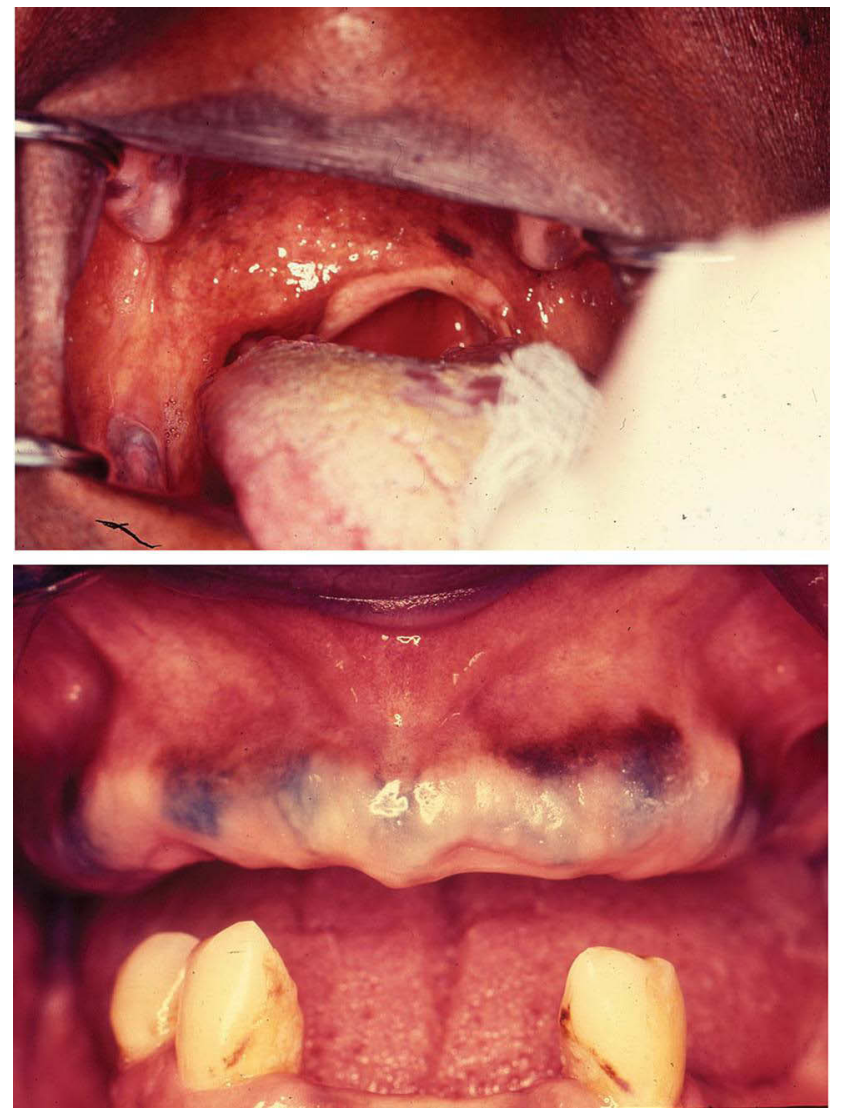

Figure 2 Case 2. (A) Photograph of missing uvula. (B) Photograph of dark bluish pigmentation on the maxillary gingiva extending bilaterally to the first premolars. with brown racial pigmentation. There was no edema, recession of the gums, or gingivitis. The dentist made a clinical diagnosis of a congenital missing uvula and drug-induced pigmentation. On further questioning, the patient stated that she had undergone gingival tattooing and had an uvulectomy performed for traditional reasons. No further treatment was required for the incidental findings, and the patient was referred for complete dental treatment.

\section{Case 3}

A 32-year-old Middle Eastern woman presented with diffuse white and red bilateral lesions on the buccal mucosa. Her chief complaint was, "I have whitish discoloration on my inner cheeks." The lesions first appeared three weeks prior to her visit, and for the last three days she felt roughness and swelling of the buccal mucosa bilaterally. No pain or burning sensations were reported. The medical history was remarkable and included irritable bowel syndrome, asthma, and skin allergies to some fabric types. The woman was taking prescribed vitamin D. The patient indicated no use of tobacco products or consumption of alcohol.

Soft tissue examination revealed thick, diffuse, white and red bilateral lesions on the buccal mucosa extending more broadly than the line of occlusion (Figure 3A and B). Upon further questioning, the patient said that she had performed dental bleaching at home approximately six months prior her visit, and then began using whitening toothpaste during the past two months. She also indicated that she had used a salt $(\mathrm{NaCl})$ and water mouth rinse for the last few weeks. The patient stated that she applied coarse salt directly in her mouth for a few seconds, then took a sip of water, and then rinsed inside her mouth.

The differential diagnosis list included chemical burn from the salt, speckled leukoplakia, and white sponge nevus. To manage her symptoms, the patient was asked to use a teaspoon of sodium bicarbonate dissolved in a cup of water as a mouth rinse and to stop using the saltwater rinse. A two-week follow-up appointment was scheduled. On the follow-up visit, soft tissue examination revealed that the buccal mucosa had completely healed (Figure 4A and B). The definitive diagnosis was chemical burn from coarse salt, and no further treatment was required.

\section{Discussion}

Here, we described the case findings of three people treated at the Oral Diagnosis Clinic at the College of Dentistry 

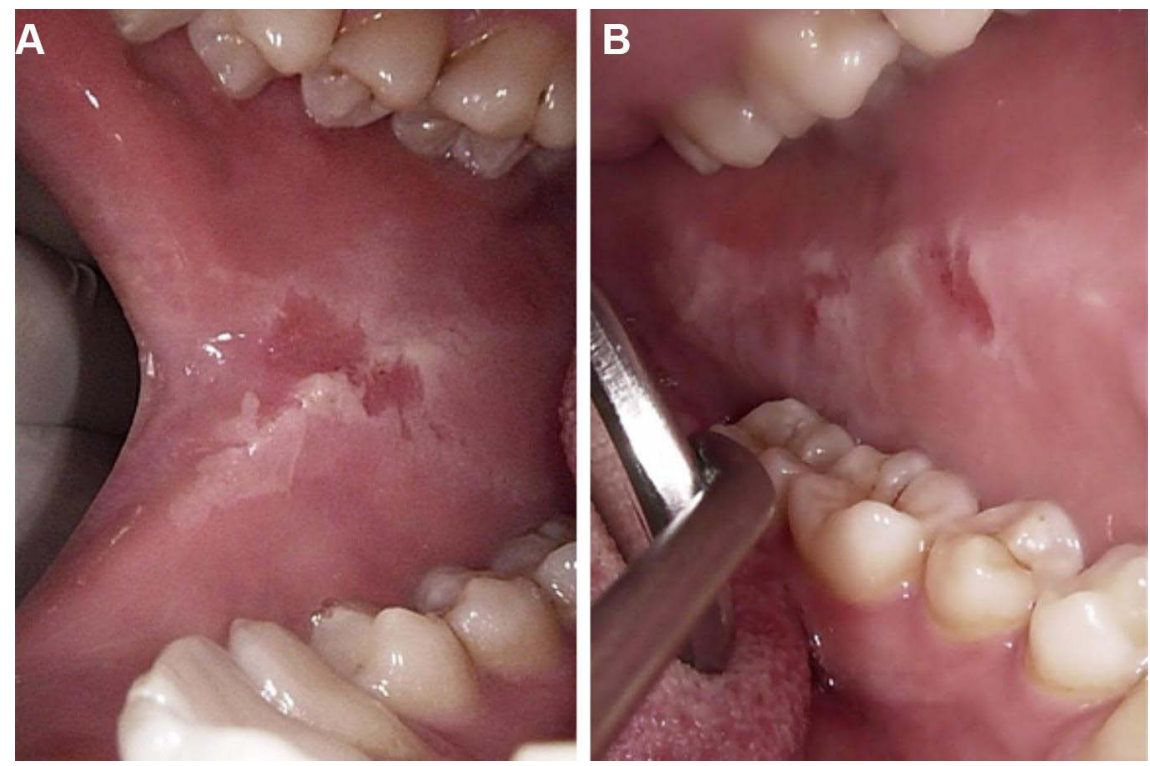

Figure 3 Case 3. Photographs of thick, diffuse, white and red bilateral lesions on the (A) right and (B) left buccal mucosa.
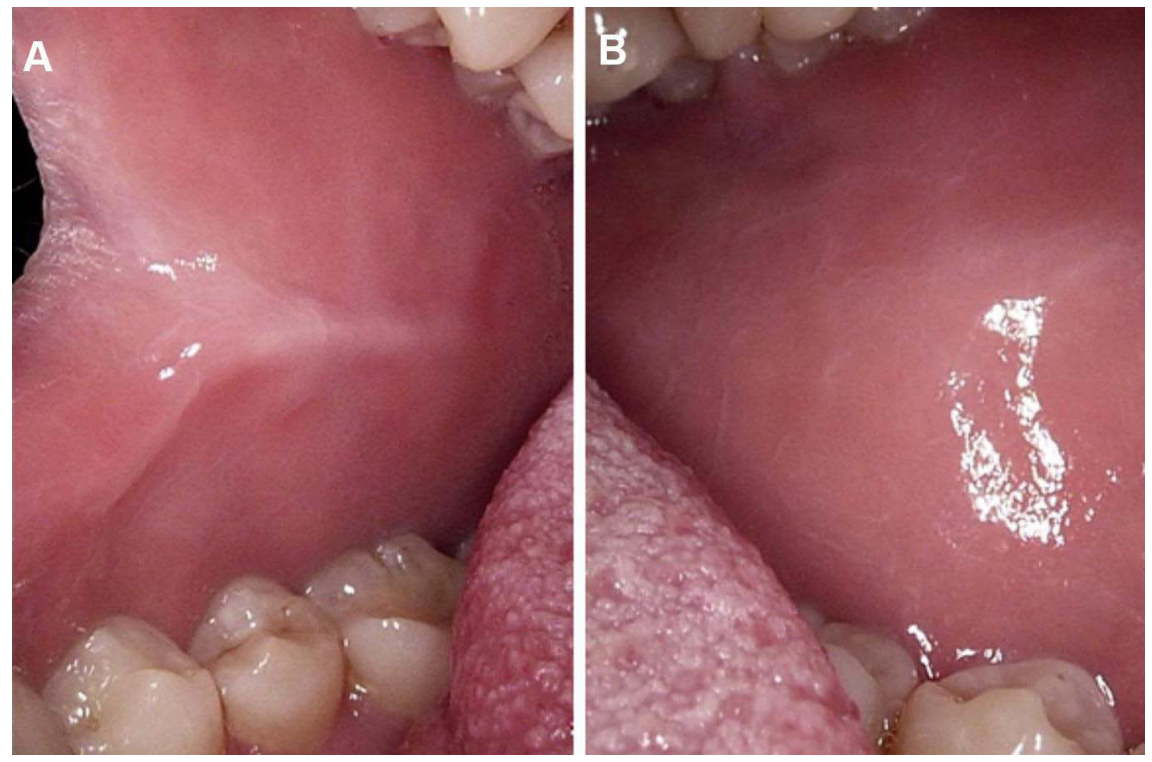

Figure 4 Case 3. Photographs of fully healed (A) right and (B) left buccal mucosa.

at King Saud University. Two patients had undergone the traditional practices of gingival tattooing and uvulectomy. The third patient had an intraoral chemical burn caused by her individual oral practices.

In Case 1 and Case 2, the dentists noted that the individuals were missing their uvulas. Upon further questioning, the dentists learned that they had been removed intentionally in accordance with a cultural practice. Traditional uvulectomy is practiced by local nonphysician healers on neonates as a cure for illnesses. For example, it is performed when the uvula is swollen and elongated.
This practice is mainly performed in the early years of life and has been reported in several studies conducted in African countries, including Ethiopia, Niger, Nigeria, and Tanzania. ${ }^{16-18}$ Traditional uvulectomy has also been reported in Saudi Arabia and Morocco. ${ }^{19,20}$ This cultural practice can be deleterious and result in life-threatening complications. A summary of patients who have been reported to be admitted to hospitals following traditional uvulectomy is provided in Table 1 . The morbidity and mortality associated with this common cultural practice is considerable. 
Table I Summary of Studies on the Traditional Practice of Uvulectomy (2000-2020)

\begin{tabular}{|c|c|c|c|c|}
\hline Author, Year & Study Type & Country & Age, Gender & Postuvulectomy Complications and Treatment/ Key Findings \\
\hline Lowe, $2004^{38}$ & Case report & Kenya & 6 months, $\mathrm{F}$ & Severe anemia treated with blood transfusion \\
\hline $\begin{array}{l}\text { Tshifularo } \\
\text { et al., } 2005^{39}\end{array}$ & Case report & $\begin{array}{l}\text { South } \\
\text { Africa }\end{array}$ & 28 years, $M$ & Postuvulectomy hemorrhage treated with cauterization \\
\hline Mitke, $2010^{40}$ & Cross-sectional & Ethiopia & $\begin{array}{c}<15 \text { years, } 423 \\
M, 640 \mathrm{~F}\end{array}$ & Traditional uvulectomy is risk factor of mother-to-child HIV transmission. \\
\hline $\begin{array}{l}\text { Adoga and } \\
\text { Nimkur, } \\
2011^{17}\end{array}$ & $\begin{array}{l}\text { Hospital-based } \\
\text { prospective }\end{array}$ & Nigeria & $108 \mathrm{M}, 57 \mathrm{~F}$ & Hemorrhage was the most common complication (I7.6\%). \\
\hline \multirow{3}{*}{$\begin{array}{l}\text { Ravesloot and } \\
\text { de Vries, } \\
20 \mathrm{II}^{4 \mathrm{I}}\end{array}$} & \multirow{3}{*}{$\begin{array}{l}\text { Case series and } \\
\text { literature } \\
\text { review }\end{array}$} & Eritrea & 42 years, $M$ & Mild obstructive sleep apnea treated with Z-palatoplasty and tonsillectomy \\
\hline & & Morocco & 51 years, $\mathrm{F}$ & Severe obstructive sleep apnea treated with positive airway pressure \\
\hline & & $\begin{array}{c}\text { Not } \\
\text { disclosed }\end{array}$ & 33 years, $M$ & $\begin{array}{l}\text { Moderate obstructive sleep apnea treated with continuous positive airway } \\
\text { pressure }\end{array}$ \\
\hline $\begin{array}{l}\text { Ibrahim, } \\
2013^{22}\end{array}$ & Case report & Nigeria & 10 days, $\mathrm{F}$ & Clavicular fracture, conservative treatment \\
\hline $\begin{array}{l}\text { Elyajouri et al., } \\
2015^{20}\end{array}$ & Case report & Morocco & 8 months, $\mathrm{F}$ & Grisel's syndrome ${ }^{\mathrm{a}}$, conservative treatment \\
\hline $\begin{array}{l}\text { Sawe et al., } \\
2015^{18}\end{array}$ & Retrospective & Tanzania & $\begin{array}{l}7 \text { months }-2 \\
\text { years, } 30 \mathrm{M} \text {, } \\
26 \mathrm{~F}\end{array}$ & $\begin{array}{l}\text { Traditional uvulectomy patients diagnosed with pneumonia (44\%), upper } \\
\text { gastrointestinal bleeding (46\%), malaria (42\%), HIV ( } 21 \%) \text {, and severe anemia } \\
\text { and malnutrition (19\%); } 21 \% \text { mortality. }\end{array}$ \\
\hline $\begin{array}{l}\text { Adebola et al., } \\
2016^{21}\end{array}$ & $\begin{array}{l}\text { Cross-sectional } \\
\text { descriptive }\end{array}$ & Nigeria & $\begin{array}{l}2-13 \text { years, } 21 \\
\mathrm{M}, 20 \mathrm{~F}\end{array}$ & $\begin{array}{l}\text { Favorable outcomes and shorter hospital stays were related to maternal } \\
\text { immunization. }\end{array}$ \\
\hline $\begin{array}{l}\text { Jimoh et al., } \\
2018^{42}\end{array}$ & Cross-sectional & Nigeria & $\begin{array}{l}319 \text { mothers, } \\
270 \text { children }\end{array}$ & $\begin{array}{l}\text { Unhygienic traditional operation performed on } 220 \text { children (8I.5\%) including: } \\
\text { uvulectomy alone ( } 42.7 \%) \text {; uvulectomy and scarification ( } 12.3 \%) \text {; and } \\
\text { uvulectomy and female genital mutilation ( } 27.3 \%) \text {. }\end{array}$ \\
\hline $\begin{array}{l}\text { Bayih et al., } \\
2020^{10}\end{array}$ & $\begin{array}{l}\text { Quantitative } \\
\text { cross-sectional }\end{array}$ & Ethiopia & $\begin{array}{l}\text { I7I M, 25I } \\
\mathrm{F} \text { neonates }\end{array}$ & $\begin{array}{c}67(15.88 \%) \text { postuvulectomy admissions of neonates; most had sepsis }(88.1 \%) \\
\text { and anemia }(55.23 \%) .\end{array}$ \\
\hline
\end{tabular}

Notes: ${ }^{a}$ Grisel's syndrome is a nontraumatic atlantoaxial subluxation, usually secondary to an infection or inflammation; it may occur after head/neck surgery. Abbreviations: M, male(s); F, female(s).

Bayih and colleagues reported that neonates delivered at home have a higher rate of traditional uvulectomy compared with those born in hospitals, and most of these neonates had postuvulectomy admissions with at least one complication. ${ }^{10}$ The use of non-sterilized instruments to perform uvulectomy may transmit life-threatening communicable diseases, and the procedure results in other complications, such as anemia and tongue and oropharyngeal injury. Common complications of traditional uvulectomy include septicemia, epistaxis, and respiratory distress, and less common complications include acute renal failure, voice changes, and neck abscesses. ${ }^{21}$ There have also been reports of several unusual complications, such as clavicular fracture, oropharyngeal stenosis, and Grisel's syndrome, following traditional uvulectomy. ${ }^{20,22}$ Adebola and colleagues found that pediatric patients with complete maternal immunization status have favorable postuvulectomy outcomes and shorter hospital stay durations. ${ }^{21}$ To reduce the incidence of traditional uvulectomy, it is important that health care providers counsel and educate parents about the role of the uvula in swallowing and preventing aspiration. In addition, the uvula plays a role in language communication and other functions. Educating parents on modern advancements for the treatment of neonatal diseases may also help reduce the incidence of this deleterious practice. ${ }^{23,24}$

The first and second cases described in this study both had diffuse dark pigmentation of the maxillary gingiva. This observation initially caused confusion. Initially, the 
patient in the first case was diagnosed with diffuse melanoma and the patient in the second case was diagnosed with drug-induced pigmentation. Taking a detailed history revealed that these patients had traditional gingival tattoos. Some ethnic minority populations use this traditional practice for cosmetic reasons to make their teeth appear whiter. This type of tattooing is practiced after puberty or before marriage in adolescent girls and young women, mainly in Ethiopia as well as in some Middle Eastern and other
African countries. ${ }^{11}$ Some cultures believe the practice of traditional gingival tattooing can alleviate diseased gingival symptoms and treat undisclosed oral diseases. ${ }^{25}$

As shown in Table 2, several studies have reported similar findings and described gingival tattooing of the maxillary and mandibular gingiva as well as of the lips; these individuals generally do not require any treatment after the procedure. Gingival tattooing is performed with non-sterilized needles or thorns to prick the gingiva to

Table 2 Summary of Studies on the Traditional Practice of Gingival Tattooing (1985-2020)

\begin{tabular}{|c|c|c|c|c|c|}
\hline Author, Year & Study Type & Country & $\begin{array}{l}\text { Age, } \\
\text { Gender }\end{array}$ & Gingival Tattoo Location and Extension & Ethnicity, Reasons \\
\hline \multirow[t]{3}{*}{ Mani, $1985^{29}$} & \multirow[t]{3}{*}{ Case series } & Yemen & $\begin{array}{l}25 \text { years, } \\
\mathrm{F}\end{array}$ & Maxillary gingiva, premolar to premolar & Traditional cosmetic \\
\hline & & Ethiopia & $\begin{array}{l}25 \text { years, } \\
\mathrm{F}\end{array}$ & Maxillary gingiva, first molar to first molar & Traditional cosmetic \\
\hline & & Ethiopia & $\begin{array}{l}40 \text { years, } \\
\mathrm{F}\end{array}$ & Facial aspect of the upper alveolar ridge & Traditional cosmetic \\
\hline $\begin{array}{l}\text { Goertz and Goos, } \\
1988^{43}\end{array}$ & Case report & Eritrea & $\begin{array}{l}25 \text { years, } \\
\mathrm{F}\end{array}$ & Maxillary gingiva, first molar to first molar & Traditional cosmetic \\
\hline $\begin{array}{l}\text { Hohenleutner and } \\
\text { Landthaler, } 1990^{44}\end{array}$ & Case report & Senegal & $\begin{array}{l}26 \text { years, } \\
\mathrm{F}\end{array}$ & Maxillary and mandibular gingiva & Traditional cosmetic \\
\hline $\begin{array}{l}\text { Telang and Ditre, } \\
1994^{45}\end{array}$ & Case report & Ethiopia & $\begin{array}{l}28 \text { years, } \\
\mathrm{F}\end{array}$ & Maxillary gingiva with interdental papilla & Traditional cosmetic \\
\hline Bukar et al., $2004^{26}$ & Cross-sectional & Nigeria & $\begin{array}{l}12-80 \\
\text { years, } \\
495 \mathrm{~F}\end{array}$ & $218(44.0 \%)$ had tattooing of lips or gingiva & Traditional cosmetic \\
\hline \multirow[t]{4}{*}{ Rawal et al., $2007^{27}$} & \multirow[t]{4}{*}{ Case series } & Mauritania & $\begin{array}{l}19 \text { years, } \\
\mathrm{F}\end{array}$ & $\begin{array}{l}\text { Maxillary vestibular gingiva, premolar to } \\
\text { premolar }\end{array}$ & $\begin{array}{l}\text { Fulani ethnic group, } \\
\text { traditional cosmetic }\end{array}$ \\
\hline & & Mauritania & $\begin{array}{l}38 \text { years, } \\
\mathrm{F}\end{array}$ & $\begin{array}{l}\text { Maxillary facial gingiva mainly involving the } \\
\text { attached gingiva }\end{array}$ & $\begin{array}{l}\text { Fulani ethnic group, } \\
\text { traditional cosmetic }\end{array}$ \\
\hline & & Mauritania & $\begin{array}{l}28 \text { years, } \\
\mathrm{F}\end{array}$ & $\begin{array}{l}\text { Maxillary vestibular gingiva, second premolar } \\
\text { to second premolar }\end{array}$ & $\begin{array}{l}\text { Soninke ethnic group, } \\
\text { traditional cosmetic }\end{array}$ \\
\hline & & Senegal & $\begin{array}{c}56 \text { years, } \\
\mathrm{F}\end{array}$ & Maxillary vestibular attached gingiva & $\begin{array}{l}\text { Mandinka ethnic group } \\
\text { traditional cosmetic }\end{array}$ \\
\hline $\begin{array}{l}\text { Brooks and } \\
\text { Reynolds, } 2007^{46}\end{array}$ & $\begin{array}{l}\text { Literature review } \\
\text { and case report }\end{array}$ & Ethiopia & $\begin{array}{l}54 \text { years, } \\
\mathrm{F}\end{array}$ & $\begin{array}{l}\text { Buccal and labial aspects of the maxillary } \\
\text { gingiva }\end{array}$ & $\begin{array}{c}\text { Treatment for } \\
\text { undisclosed oral disease }\end{array}$ \\
\hline $\begin{array}{l}\text { Tinklepaugh and } \\
\text { Norton, } 20 \mathrm{II}^{47}\end{array}$ & Case report & Senegal & $\begin{array}{c}27 \text { years, } \\
\mathrm{F}\end{array}$ & Maxillary gingiva and upper and lower lips & Traditional cosmetic \\
\hline \multirow[t]{2}{*}{$\begin{array}{l}\text { Calcaterra et al., } \\
2015^{11}\end{array}$} & \multirow[t]{2}{*}{ Case report } & Ethiopia & $\begin{array}{c}37 \text { years, } \\
\mathrm{F}\end{array}$ & $\begin{array}{l}\text { Mandibular and maxillary vestibular } \\
\text { gingiva, second premolar to second premolar }\end{array}$ & Traditional cosmetic \\
\hline & & Ethiopia & $\begin{array}{c}45 \text { years, } \\
\mathrm{F}\end{array}$ & Maxillary vestibular gingiva & Traditional cosmetic \\
\hline
\end{tabular}

Abbreviations: M, male(s); F, female(s). 
make the gingiva bleed, without local anesthesia. A mixture of materials, such as seeds of Acacia nilotica var, charcoal, burnt seeds, herbs, lampblack, and soot, are then applied to the pricked gingiva. Traditional gingival tattooing may lead to infectious disease transmission. ${ }^{26}$

Although, gingival tattooing is mainly diagnosed clinically, radiopaque signs may be detected in radiographs depending on the substance used. ${ }^{27}$ Depending on the number of gingival tattooing sessions and recency of the last session, the color of gingival tattoos varies from grayish to dark blue. ${ }^{28}$ Mani (1985) reported three cases of patients with gingival tattoos in Riyadh, Saudi Arabia, and noted that diagnostic problems may arise with differentiating these tattoos from other pigmented lesions. ${ }^{29}$ Traditional gingival tattoos might be misdiagnosed as physiological (a.k.a. racial) pigmentation, which is common in dark-skinned people. Intentional tattooing should also be distinguished from amalgam tattoos and graphite tattoos, which are caused by accidental impregnation of these materials into the oral mucosa. Furthermore, gingival tattoos might be misinterpreted as melanocytic lesions, such as melanotic macules or diffuse melanoma. Oral pigmentation can also be caused by systemic diseases, such as Peutz-Jeghers syndrome and Addison disease, as well as by some medications and heavy

Table 3 Summary of Studies on Individual Practices Involving the Misuse of Chemical Agents on the Oral Mucosa (1978-2020)

\begin{tabular}{|c|c|c|c|c|}
\hline $\begin{array}{l}\text { Author, } \\
\text { Year }\end{array}$ & $\begin{array}{l}\text { Study } \\
\text { Type }\end{array}$ & Chemical Agent & $\begin{array}{l}\text { Age, } \\
\text { Gender }\end{array}$ & Oral Findings \\
\hline $\begin{array}{l}\text { Rubright } \\
\text { et al., } 1978^{32}\end{array}$ & $\begin{array}{l}\text { Case } \\
\text { report }\end{array}$ & Synthetic dentifrice detergents (foaming agents) & $\begin{array}{c}50 \\
\text { years, } F\end{array}$ & $\begin{array}{c}\text { Grayish-white desquamation with gelatinous membranes } \\
\text { on floor of mouth, lips, vestibules, and gingiva }\end{array}$ \\
\hline $\begin{array}{l}\text { Touyz and } \\
\text { Hille, } 1984^{33}\end{array}$ & $\begin{array}{l}\text { Case } \\
\text { report }\end{array}$ & $\begin{array}{l}\text { Multiple mouthwashes and fruit juices to treat } \\
\text { periodontal disease }\end{array}$ & $\begin{array}{c}55 \\
\text { years, } M\end{array}$ & $\begin{array}{l}\text { White chemical burn on upper and lower attached } \\
\text { gingiva with small red dots }\end{array}$ \\
\hline \multirow[t]{2}{*}{$\begin{array}{l}\text { Baruchin } \\
\text { et al., } 1991^{12}\end{array}$} & \multirow[t]{2}{*}{$\begin{array}{l}\text { Case } \\
\text { reports }\end{array}$} & Silver nitrate sticks to treat aphthous ulcers & $\begin{array}{c}20 \\
\text { years, } M\end{array}$ & Substantial sloughing of mucosa from margin of tongue \\
\hline & & $\begin{array}{l}\text { Gauze soaked in Arrack to alleviate severe } \\
\text { dental pain }\end{array}$ & $\begin{array}{c}50 \\
\text { years, } M\end{array}$ & $\begin{array}{l}\text { White sloughing lesion of the mucosa adjacent to the } \\
\text { maxillary left first premolar }\end{array}$ \\
\hline $\begin{array}{l}\text { Moghadam } \\
\text { et al., } 1999^{48}\end{array}$ & $\begin{array}{l}\text { Case } \\
\text { report }\end{array}$ & $\begin{array}{l}\text { Undiluted OTC mouthwash with high alcohol } \\
\text { content to treat gum infection }\end{array}$ & $\mathrm{F}$ & Severe mucosal injuries \\
\hline $\begin{array}{l}\text { Sapir and } \\
\text { Bimstein, } \\
2000^{49}\end{array}$ & $\begin{array}{l}\text { Case } \\
\text { report }\end{array}$ & Anti-inflammatory cholinsalicylate paste & $\begin{array}{c}8 \text { years, } \\
M\end{array}$ & Mucosal burns \\
\hline $\begin{array}{l}\text { Rostami and } \\
\text { Brooks, } \\
2011^{50}\end{array}$ & $\begin{array}{l}\text { Case } \\
\text { report }\end{array}$ & $\begin{array}{l}\text { Excessive use of OTC } 3 \% \text { hydrogen peroxide to } \\
\text { treat discomfort following seafood ingestion }\end{array}$ & ND & $\begin{array}{l}\text { Extensive chemical burns of sublingual and buccal mucosa } \\
\text { and gingiva }\end{array}$ \\
\hline $\begin{array}{l}\text { Dayakar } \\
\text { et al., } 2012^{34}\end{array}$ & $\begin{array}{l}\text { Case } \\
\text { report }\end{array}$ & $\begin{array}{l}\text { Tetracycline hydrochloride tablets to treat } \\
\text { periodontitis }\end{array}$ & $\begin{array}{c}65 \\
\text { years, } M\end{array}$ & $\begin{array}{l}\text { Yellowish white slough on attached gingiva extending } \\
\text { from lower canine to canine on labial surface }\end{array}$ \\
\hline \multirow{3}{*}{$\begin{array}{l}\text { Boras et al., } \\
2015^{51}\end{array}$} & \multirow{3}{*}{$\begin{array}{l}\text { Case } \\
\text { reports }\end{array}$} & Tinctura adstringens to treat dental pain & M & Chemical burn on upper left gingiva \\
\hline & & Propolis (bee glue) to treat gingivitis & $\mathrm{F}$ & $\begin{array}{l}\text { Chemical burn on upper attached gingiva of right lateral } \\
\text { incisor and canine }\end{array}$ \\
\hline & & Gentian violet to treat gingivitis & $\mathrm{F}$ & $\begin{array}{l}\text { Ulcerative/exfoliative lesions on upper labial mucosa and } \\
\text { gingiva }\end{array}$ \\
\hline $\begin{array}{l}\text { Vargo et al., } \\
2017^{30}\end{array}$ & $\begin{array}{l}\text { Case } \\
\text { report }\end{array}$ & Crushed raw garlic to treat dental pain & $\begin{array}{c}49 \\
\text { years, } M\end{array}$ & $\begin{array}{c}\text { Grayish white sloughing plaque with irregular borders on } \\
\text { attached gingiva and alveolar mucosa in area of maxillary } \\
\text { right molars }\end{array}$ \\
\hline $\begin{array}{l}\text { Brooks, } \\
2017^{52}\end{array}$ & $\begin{array}{l}\text { Case } \\
\text { report }\end{array}$ & Misuse of OTC oral whitening rinses & ND & Gingival chemical burns \\
\hline
\end{tabular}

Abbreviations: F, female(s); M, male(s); ND, not disclosed; OTC, over-the-counter. 
metal intoxication. ${ }^{11}$ Dentists should evaluate the color and pattern of any oral cavity pigmentation carefully to avoid unnecessary investigations or misdiagnoses. In cases with unclear histories and if pigmentation does not reflect exogenous origins, a biopsy should be considered to reach a definitive diagnosis.

In the third case of the present report, the patient had misguided oral hygiene habits, including putting solid coarse salt in her mouth followed by a water rinse. The patient placed salt in direct contact with soft oral tissues, resulting in a chemical burn of the soft buccal mucosa. Multiple studies have reported similar oral mucosal burns due to the misuse of various agents on the oral mucosa, such as silver nitrate, dental detergents, and medications. ${ }^{12,30,31}$ Furthermore, mouthwashes and some home remedies (eg, crushed garlic to relieve dental pain) can cause oral ulcers. ${ }^{12,30-33}$ Chemical agents can cause diverse effects when they come in contact with the oral mucosa (Table 3 ).

The effects of chemical agents on the oral mucosa can vary in severity, ranging from mucosa sloughing to complete destruction of the oral epithelium extending beyond the basement membrane into the submucosa. ${ }^{34}$ Many factors play roles in the resultant soft tissue injuries, including the concentration of the chemical used and its mechanism of action, the level of infiltration of the chemical into the soft tissues, and the duration of soft tissue exposure to the substance. $^{35}$ As demonstrated in the presently reported cases, detailed questioning of the patient is critical for reaching an accurate diagnosis and treatment plan. In such cases, treatment usually involves removing the insulting agent and pain management either by systemic or topical analgesic application. $^{34}$ In our third case, because the patient was asymptomatic, reassuring patient education was sufficient.

Accurate diagnosis and treatment of oral conditions is critical given the profound impact that oral disease can have on quality of life. Indeed, a large systemic review of the relationship between oral and dental disease with quality of life indicated that periodontal disease can exert a profoundly negative impact on quality of life, with greater severity of the disease having a more pronounced impact. ${ }^{36}$ At the same time, there is a risk of administering unnecessary treatments, which can be costly and, more importantly, harmful to patients if patients are misdiagnosed with diseases such as periodontitis. ${ }^{37}$

\section{Conclusion}

The cultural practices described in this report are generally performed in less developed communities in Africa, particularly those with low literacy levels and low socioeconomic statuses. Thus, implementing free educational programs about the adverse effects of these practices may help reduce their incidence. Furthermore, dentists must develop good relationships with their patients so that they are considered trusted sources of education. Cultural and individual practices must be considered when recording patient histories to reduce the risk of misdiagnosis. Consideration of these practices will help dentists to provide appropriate treatment plans and high-quality oral health care services while respecting their patients' cultural beliefs.

\section{Institutional Review Board Statement}

The study was conducted according to the guidelines of the Declaration of Helsinki, and approved by the Institutional Review Board/Ethics Committee of King Saud University Institutional Review Board (protocol code E-20-4746, 30.04.2020, Ref. No. 20/0321/IRB).

\section{Informed Consent Statement}

Informed consent was obtained from all subjects involved in the study.

\section{Acknowledgments}

The authors wish to acknowledge the kind assistance of a professional scientific editor at Write Science Right.

\section{Funding}

This research received no external funding.

\section{Disclosure}

The authors declare no conflict of interest.

\section{References}

1. Vivek S, Jain J, Simon SP, Battur H, Tikare S, Mahuli A. Understanding oral health beliefs and behavior among Paniyan tribals in Kerala, India. J Int Oral Health. 2012;4(3):23.

2. Galanti G-A. Caring for Patients from Different Cultures. University of Pennsylvania Press; 1991.

3. Johnston J. Improving utilization of dental services by understanding cultural difference. Int Dent J. 1993;43(5):506-511.

4. Loh F, Yeo J. Talisman in the orofacial region. Oral Surg, Oral Med, Oral Pathol. 1989;68(3):252-255. doi:10.1016/0030-4220(89)90204-1

5. Rasmussen P, Elhassan FE, Raadal M. Enamel defects in primary canines related to traditional treatment of teething problems in Sudan. Int J Pediatric Dentistry. 1992;2(3):151-155. doi:10.1111/ j.1365-263X.1992.tb00028.x

6. Musinguzi N, Kemoli A, Okullo I. Prevalence and dental effects of infant oral mutilation or Ebiino among 3-5 year-old children from a rural district in Uganda. BMC Oral Health. 2019;19(1):1-7. doi:10.1186/s12903-019-0890-6 
7. Wandera MN, Kasumba B. "Ebinyo"-the practice of infant oral mutilation in Uganda. Front Public Health. 2017;5:167. doi:10.3389/fpubh.2017.00167

8. Bataringaya A, Ferguson M, Lalloo R. The impact of ebinyo, a form of dental mutilation, on the malocclusion status in Uganda. Community Dent Health. 2005;22(3):146-150.

9. Kemoli AM. Raising the awareness of infant oral mutilation - myths and facts. Contemp Clin Dent. 2015;6(Suppl 1):S137. doi:10.4103/ 0976-237X.166843

10. Alebachew Bayih W, Minuye Birhan B, Yeshambel Alemu A. The burden of traditional neonatal uvulectomy among admissions to neonatal intensive care units, North Central Ethiopia, 2019: a triangulated crossectional study. PLoS One. 2020;15(7):e0234866. doi:10.1371/journal.pone.0234866

11. Calcaterra R, Di Girolamo M, Toni M, Mirisola C, Baggi L. Blue gingiva: a possible diagnostic pitfall in dark skinned patients. Oral Implantol (Rome). 2015;8:29-32.

12. Baruchin AM, Lustig JP, Nahlieli O, Neder A. Burns of the oral mucosa: report of 6 cases. J Cranio-Maxillofacial Surg. 1991;19 (2):94-96. doi:10.1016/S1010-5182(05)80615-8

13. Isola G, Lo Giudice A, Polizzi A, Alibrandi A, Murabito P, Indelicato F. Identification of the different salivary Interleukin-6 profiles in patients with periodontitis: a cross-sectional study. Arch Oral Biol. 2021;122:104997. doi:10.1016/j.archoralbio.2020.104997

14. Isola G, Polizzi A, Alibrandi A, Williams RC, Lo Giudice A. Analysis of galectin-3 levels as a source of coronary heart disease risk during periodontitis. J Periodontal Res. 2021;56(3):597-605. doi: $10.1111 /$ jre. 12860

15. Isola G, Polizzi A, Santonocito S, Alibrandi A, Williams RC. Periodontitis activates the NLRP3 inflammasome in serum and saliva. J Periodontol. 2021. doi:10.1002/jper.21-0049

16. Gebrekirstos K, Abebe M, Fantahun A. A cross sectional study on factors associated with harmful traditional practices among children less than 5 years in Axum town, North Ethiopia, 2013. Reprod Health. 2014;11(1):1-7. doi:10.1186/1742-4755-11-46

17. Adoga AA, Nimkur TL. The traditionally amputated uvula amongst Nigerians: still an ongoing practice. Int Scholarly Res Notices. 2011;2011:704924.

18. Sawe H, Mfinanga J, Ringo F, Mwafongo V, Reynolds T, Runyon M. Morbidity and mortality following traditional uvulectomy among children presenting to the muhimbili national hospital emergency department in Dar es Salaam, Tanzania. Emerg Med Int. 2015;2015:108247. doi:10.1155/2015/108247

19. Abdullah MA. Traditional practices and other socio-cultural factors affecting the health of children in Saudi Arabia. Ann Trop Paediatr. 1993;13(3):227-232. doi:10.1080/02724936.1993.11747650

20. Elyajouri A, Assermouh A, Abilkacem R, Agadr A, Mahraoui C. Grisel's syndrome: a rare complication following traditional uvulectomy. Pan African Med J. 2015;20:62. doi:10.11604/ pamj.2015.20.62.5930

21. Adebola SO, Ogunkeyede SA, Obebe FA, Olaniyan OD, Fawole OB, Salman A. Profile of pediatric traditional uvulectomy in North-West Nigeria: the need for caution and education. Int $J$ Pediatr Otorhinolaryngol. 2016;88:194-198. doi:10.1016/j.ijporl.2016.07.011

22. Ibrahim A. Clavicular fracture following uvulectomy and traditional hair barbing: a case report. J Family Med Primary Care. 2013;2 (4):390. doi:10.4103/2249-4863.123935

23. Aaba A. National strategy and action plan on harmful traditional practices (HTPs) against women and children in ethiopia federal democratic republic of ethiopia ministry of women (MoWCYA). Children and Youth Affairs; 2013:1-61.

24. Federal Democratic Republic of Ethiopia (Ministry of Health). Basic emergency obstetric \& newborn care (BEmONC) training manual; 2018
25. Diallo P, Diallo-Seck A, Sembene M, Ngom-Ndoye M, Moreau J, Diene A. Gingival tattooing in senegal: the" Pimpi". consequence on the carbon parodonte. Tropical Dental J. 1995;4-6.

26. Bukar A, Danfillo I, Adeleke O, Ogunbodede E. Traditional oral health practices among Kanuri women of Borno State, Nigeria. Odonto-Stomatologie Tropicale Tropical Dental J. 2004;27 (107):25-31

27. Rawal SY, Burrell R, Hamidi CS, Kalmar JR, Tatakis DN. Diffuse pigmentation of maxillary attached gingiva: four cases of the cultural practice of gingival tattoo. J Periodontol. 2007;78(1):170-176. doi:10.1902/jop.2007.060234

28. Gbane M, Assoumou M, Abouattier-Mansilla E. Étude clinique de la gencive tatouée [A clinical study of gingival tattooing]. OdontoStomatologie Tropicale. 1998;28-32.

29. Mani N. Gingival tattoo: a hitherto undescribed mucosal pigmentation. Quintessence Int. 1985;16(2):157-159.

30. Vargo RJ, Warner BM, Potluri A, Prasad JL. Garlic burn of the oral mucosa: a case report and review of self-treatment chemical burns. $J \mathrm{Am}$ Dental Assoc. 2017;148(10):767-771. doi:10.1016/j.adaj.2017.02.053

31. Kowitz GM, Lucatorto FM, Cherrick HM. Effects of mouthwashes on the oral soft tissues. J Oral Med. 1976;31(2):47-50.

32. Rubright WC, Walker JA, Karlsson UL, Diehl DL. Oral slough caused by dentifrice detergents and aggravated by drugs with antisialic activity. $J$ Am Dental Assoc. 1978;97(2):215-220. doi:10.14219/jada.archive.1978.0260

33. Touyz LZ, Hille JJ. A fruit-mouthwash chemical burn. Report of a case. Oral Surg Oral Med Oral Pathol. 1984;58(3):290-292. doi:10.1016/0030-4220(84)90057-4

34. Dayakar MM, Pai PG, Madhavan SS. "Tetracycline hydrochloride chemical burn" as self-inflicted mucogingival injury: a rare case report. J Indian Soc Periodontol. 2012;16(2):282. doi:10.4103/ 0972-124X.99278

35. Middleton C, Berwick J, Adamson D. Chemical burn in the oral cavity. US Army Med Dep J. 1995;8:10-12.

36. Ferreira MC, Dias-Pereira AC, Branco-de-almeida LS, Martins CC, Paiva SM. Impact of periodontal disease on quality of life: a systematic review. $J$ Periodontal Re. 2017;52(4):651-665. doi:10.1111/jre.12436

37. Ng E, Tay JRH, Ong MMA. Minimally invasive periodontology: a treatment philosophy and suggested approach. Int $J$ Dent. 2021;2021:2810264. doi:10.1155/2021/2810264

38. Lowe KR. Severe anemia following uvulectomy in Kenya. Mil Med. 2004;169(9):712. doi:10.7205/MILMED.169.9.712

39. Tshifularo M, Joseph C, Ogunbanjo G. Post-tonsillectomy haemorrhage following traditional uvulectomy in an adult patient. South African Family Practice. 2005;47(1):46. doi:10.1080/ 20786204.2005.10873171

40. Mitke YB. Bloody traditional procedures performed during infancy in the oropharyngeal area among HIV+ children: implication from the perspective of mother-to-child transmission of HIV. AIDS Behav. 2010;14(6):1428-1436. doi:10.1007/s10461-010-9681-4

41. Ravesloot M, De Vries N. 'A good shepherd, but with obstructive sleep apnoea syndrome': traditional uvulectomy case series and literature review. J Laryngol Otol. 2011;125(9):982. doi:10.1017/ S0022215111001526

42. Jimoh AO, Adaji SE, Adelaiye $\mathrm{H}$, et al. A cross-sectional study of traditional practices affecting maternal and newborn health in rural Nigeria. Pan Afr Med J. 2018;31:64.

43. Goertz J, Goos M. Traditional tattooing of the gingiva: an Eritrean folk medicine practice. Arch Dermatol. 1988;124(7):1018-1019. doi:10.1001/archderm.1988.01670070020011

44. Hohenleutner U, Landthaler M. Traditional tattooing of the gingiva: successful treatment with the argon laser. Arch Dermatol. 1990;126 (4):547. doi:10.1001/archderm.1990.01670280133037 
45. Telang GH, Ditre CM. Blue gingiva, an unusual oral pigmentation resulting from gingival tattoo. $J$ Am Acad Dermatol. 1994;30 (1):125-126. doi:10.1016/S0190-9622(08)81898-1

46. Brooks JK, Reynolds MA. Ethnobotanical tattooing of the gingiva: literature review and report of a case. J Am Dental Assoc. 2007;138 (8):1097-1101. doi:10.14219/jada.archive.2007.0322

47. Tinklepaugh AJ, Norton SA. Traditional gingival tattooing of maxillary denture. Arch Dermatol. 2011;147(11):1334-1335. doi:10.1001/archdermatol.2011.314

48. Moghadam B, Gier R, Thurlow T. Extensive oral mucosal ulcerations caused by misuse of a commercial mouthwash. Cutis. 1999;64 (2):131-134.
49. Sapir S, Bimstein E. Cholinsalicylate gel induced oral lesion: report of case. J Clin Pediatr Dent. 2000;24(2):103-106.

50. Rostami AM, Brooks JK. Intraoral chemical burn from use of $3 \%$ hydrogen peroxide. Gen Dent. 2011;59(6):504-506.

51. Boras VV, Brailo V, Andabak Rogulj A, Vidovic Juras D, Gabric D, Vrdoljak DV. Oral adverse reactions caused by over-the-counter oral agents. Case Rep Dent. 2015;2015:196292.

52 . Brooks JK. Chemical burn to the gingiva after misuse of an over-thecounter oral whitening mouthwash. Gen Dent. 2017;65:34-36.

\section{Publish your work in this journal}

Clinical, Cosmetic and Investigational Dentistry is an international, peer-reviewed, open access, online journal focusing on the latest clinical and experimental research in dentistry with specific emphasis on cosmetic interventions. Innovative developments in dental materials, techniques and devices that improve outcomes and patient satisfaction and preference will be highlighted. The manuscript management system is completely online and includes a very quick and fair peer-review system, which is all easy to use. Visit http://www.dovepress.com/testimonials.php to read real quotes from published authors. 